\title{
The Effect of Capital Expenditure and Market Share on Profits per Region in an Indonesian Mobile Telecommunications Company
}

\author{
Nursakti Niko Rosandy ${ }^{1}$, Aria Farah Mita ${ }^{1 *}$ \\ ${ }^{1}$ Faculty of Economics and Business, Universitas Indonesia, Jakarta Pusat 10430, Indonesia \\ *aria.farahmita@ui.ac.id
}

\begin{abstract}
This research aims to examine the effect of capital expenditure (CAPEX) and market share on profits per region in an Indonesian mobile telecommunications company. This research uses all regions (10) during the period 2009-2016 (8 years), resulting in 80 observations. The research uses a panel data regression model and shows that CAPEX and market share have a positive influence on profit. The company in the mobile telecommunications industry should consider the demand from the aspects of customer needs and the need to regularly update technology; therefore, the company should be more selective in making investments. The selection of the performance periods used plays a role in determining whether or not CAPEX has any effect on profit, as evidenced in the model using the t-1 and t-3 periods. CAPEX does not have an influence on profit in the $t-1$ period, whereas CAPEX does have a positive influence on profit in the $\mathrm{t}-3$ period. Market share has a positive influence on profit. With a large market share, the company has strengths including economies of scale, market power, and quality management.
\end{abstract}

Keywords: Capital Expenditure, Market Share, Profit, Region, Mobile Telecommunication.

\section{INTRODUCTION}

Over the last few years, the Indonesian telecommunications industry has been growing rapidly. This has resulted from actual economic growth from the Presidential Regulation Governmental Working Plan (Perpres RKP ${ }^{1}$ ) of $5.3 \%$ in 2016, with a projection for growth in the range of $5.5-5.9 \%$ for 2017 . The information and communications sector saw the biggest growth compared to other sectors, with actual growth in 2016 of $10.7 \%$ and a 2017 projection in the range of $10.5 \%-10.9 \%$. This high growth was dominated by cellular (mobile) telecommunications. There are currently three major operating providers: Telkomsel, Indosat Ooredoo, and XL Axiata.

This research was conducted on an Indonesian mobile telecommunications company against a backdrop of the company as the market leader, with a market share of more than $50 \%^{2-4}$. Based on its financial performance from 2016, the company recorded a gain (net income) of Rp28 trillion with a level of earnings (net income margin) of $32.5 \%$ and an investment ratio of capital expenditure to revenue of $15.0 \%$.

The level of profits is one of the tools used to measure company performance. In an attempt to meet the market demand, and to maintain or enhance its market share, which in turn is expected to increase business profits, the company faces a number of decisions, one of which is a decision on capital expenditure (investment) through capital expenditure (CAPEX). Company capital expenditure through acquisition and asset use is directed to gain benefit or incoming cash flow across more than one operating/accounting period.

With geographic segmentation as the focus, varied profile on unit of analysis per region became the attraction for conducting this research. The selection of unit analysis at the regional level looks at the condition of the company, the management of which is currently focused on a marking zone strategy.

There is a contradictory thing on the previous research, although we do see a tendency for CAPEX and market share to affect the level of profit. However, the fact that there is not always greater CAPEX will further affect the level of profit, and neither does greater market share further affect the level of profit. Therefore, the purpose of this study is to analyze the effect of CAPEX and market share on profit per region in the company.

\section{LITERATURE REVIEW AND HYPOTHESIS DEVELOPMENT}

According to Jensen and Meckling ${ }^{5}$, the agency relationship is a contract in which one or more parties (principals) are bound by another party (agent) to carry out work in which the delegation of decision-making authority is given to the agent. To maintain the continuity of the company, some decisions must be made by the agent or management, one of which relates to capital spending (investment) decisions through CAPEX. The company's capital expenditure, according to Hasnawati ${ }^{6}$, through the acquisition and use of assets, is directed to gain the benefit of incoming cash flow across more than one operating/accounting period.

Referring to the research results of Mutiara et $\mathrm{al}^{7}$, Cho et al. ${ }^{8}$, and Jiang et al. ${ }^{9}$, the hypothesis of the research between the independent variable CAPEX and the dependent variable level of profit is as follows: 
Ha1: CAPEX has an influence on level of profit per region in the company.

Expansion is undertaken to increase market share or improve quality to maintain market share, and related to these efforts the company must continue its efforts to meet the stockholder rate of return, a main indicator of which is level of profit. In the era of tight competition, Cooper et $\mathrm{al}^{10}{ }^{10}$ state that companies and managers are more concerned with market share and level of profit or profitability. In reference to Chu et al. ${ }^{11}$, Laverty ${ }^{12}$, and Buzzell et al. ${ }^{13}$, the hypothesis between the independent variable market share and dependent variable level of profit is as follows:

Ha2: Market share has an influence on level of profit per region in the company.

This research also considers the control variable size. Based on research by Toyin et al. ${ }^{14}$ and Kaen et al. ${ }^{15}$, this control variable is assumed to influence level of profit. Profitability can be improved through methods of efficient fixed asset management, one of which is through the selection of fixed assets that correspond to the needs of the company.

\section{RESEARCH METHODOLOGY}

This research takes the form of a company case study and empirical research. Empirical research is used to test the hypotheses that have been developed. The type of data is secondary, taken from companies in the period 20092016. The research objects are CAPEX, market share, entity size, and level of profit. The research subject is the region in the company. Unit of analysis: region level. Population: all regions in the company. Sample: 10 regions. Research period: 2009-2016 (8 years).

The analysis used in this research is the data panel regression analysis. The research model used to test the hypotheses in this research is as follows:

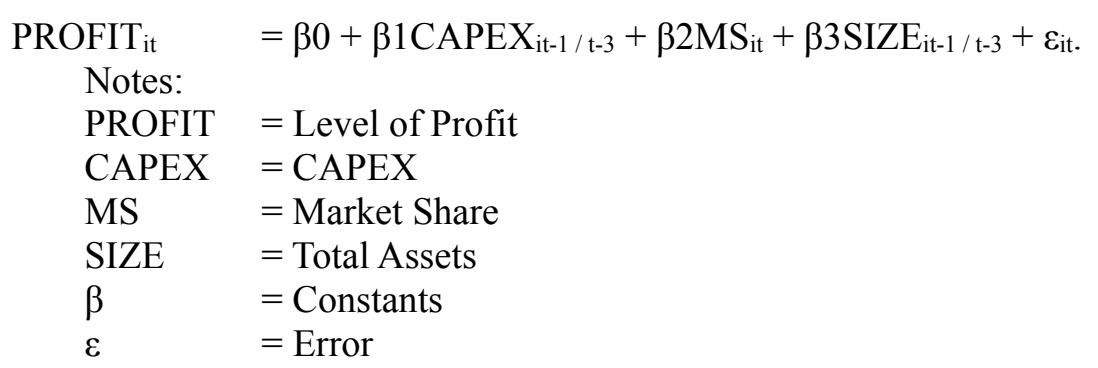

\section{RESULTS AND DISCUSSIONS}

Table.1. Hypothesis Examination Results in Period t-1.

\begin{tabular}{lrrrr}
\hline \multicolumn{1}{c}{ Variable } & Coef. & Sd. Error & \multicolumn{1}{c}{ t-Stat. } & \multicolumn{1}{c}{ Prob. } \\
\hline C & 1,50 & 0,54 & 2,77 & 0,01 \\
CAPEX t-1 & 0,02 & 0,09 & 0,19 & 0,85 \\
Market Share t & 0,40 & 0,11 & 3,55 & $0,00^{* *}$ \\
Entity Size t-1 & $-0,03$ & 0,02 & $-1,75$ & $0,09^{*}$ \\
R-Squared & & & & 0,93 \\
Adjusted R-Squared & & & & 0,91 \\
F-statistic & & & & 69,78 \\
Prob (F-statistic) & & & & 0,00 \\
\hline
\end{tabular}

Notes:

Observation: 80 , by conducting winsorization for outliers set based on a limit 3 times the standard deviation from the average value.

Panel data regression model: Fixed effect.

CAPEX $=$ Entire expenditure incurred in terms of asset acquisition that has benefits over one operating (accounting) period. Measured by proxy CAPEX per total assets at period $\mathrm{t}-1$.

Market Share $=$ Part of the market that is dominated by a single company, or percentage of the company's sales against the total sales of largest competitors at period t. Measured by proxy market share at period t.

Size $=$ Total assets is all wealth owned by the company at period $\mathrm{t}-1$.

Level of profit $=$ Net profit gained by the company. Measured by proxy profitability at period $t$.

*significant in alpha $=0.10$

$* *$ significant in alpha $=0.05$

The appropriate panel data regression model for use in this research is fixed effect, in accordance with the 
results obtained from a Chow and Hausman test. This research model is also free of the following classical assumptions: test of normality, multicollinearity, heteroscedasticity, and autocorrelation.

Table.2. Hypothesis Examination Results in Period t-3.

\begin{tabular}{lrrrr}
\hline \multicolumn{1}{c}{ Variable } & Coef. & Sd. Error & \multicolumn{1}{c}{ t-Stat. } & \multicolumn{1}{c}{ Prob. } \\
\hline C & 0,38 & 0,47 & 0,81 & 0,42 \\
CAPEX t-3 & 0,15 & 0,07 & 2,31 & $0,02^{* *}$ \\
Market Share t & 0,29 & 0,10 & 2,87 & $0,01^{* *}$ \\
Entity Size t-3 & 0,01 & 0,02 & 0,30 & 0,77 \\
R-Squared & & & & 0,93 \\
Adjusted R-Squared & & & & 0,92 \\
F-statistic & & & & 77,64 \\
Prob (F-statistic) & & & & 0,00 \\
\hline
\end{tabular}

Notes:

Observation: 80 , by conducting winsorization for outliers set based on a limit 3 times the standard deviation from the average value.

Panel data regression model: Fixed effect.

CAPEX $=$ Entire expenditure incurred in terms of asset acquisition that has benefits over one operating (accounting) period. Measured by proxy CAPEX per total assets at period $t-3$.

Market Share $=$ Part of the market that is dominated by a single company, or percentage of the company's sales against the total sales of its largest competitors at period t. Measured by proxy market share at period t.

Size $=$ Total assets is all wealth owned by the company at period $\mathrm{t}-3$.

Level of profit $=$ Net profit gained by the company. Measured by proxy profitability at period $t$.

*significant in alpha $=0,10$

$* *$ significant in alpha $=0,05$

In light of these F-test results, it can be expressed that this regression model is appropriate to explain the influence of CAPEX and market share on the level of profit, while the t-test results show that CAPEX, market share, and size can be concluded to have an impact on level of profit per region in the company. From adjusted value, it is concluded that both independent variables affect the dependent variable by the amount of 0.92 , with the remaining 0.08 affected by the other variable.

\section{CAPEX Influence against Level of Profit}

In empirical research conducted throughout the company's regions, it can be proved that CAPEX period t-3 has a positive influence on earnings level. This is in line with the majority of previous research that proves that CAPEX has an influence on profitability, among others: Jiang et al. ${ }^{9}$, Chung et al. ${ }^{16}$, Cho et al. ${ }^{8}$, and Mutiara et al. ${ }^{7}$.

Things that also need to be considered related to the effect of CAPEX on the rate of profit are the time of return on investment funds, the period when the company will start to earn profits. The timing of the refund varies by industry, company, and even by project. In this study the CAPEX used has been simulated using the t- 1 and t-3 investment periods. In this research, CAPEX period $t-1$ is concluded as having no effect on earnings level, while CAPEX period $t-3$ has an influence on earnings level. Two periods of CAPEX are used to determine the different impacts of level of profit. When compared to Jiang et al. ${ }^{9}$, the study period is divided into two periods of investment or current period (1992-1996) and period of performance or future (1997-2002), the period of performance in the research is 5 years ahead.

A relatively large CAPEX value is indeed aimed at satisfying customer needs and the need to renew technology. This can be confirmed through Network Solution Scenario companies, where the percentage of allocated CAPEX can be classified based on its purpose, from the largest percentage to the smallest: Capacity $+/-60 \%$, Quality $+/-$ $30 \%$, and the remaining Coverage $+/-10 \%$. Capital expenditure in the form of investment for capacity enlargement is conducted through the addition of a Network Element in the form of Infrastructure and Equipment, improvement of capacity, as well as through Software and Hardware or optimization of spectrum. From these scenarios selected by the company, it can be concluded that the company's center points, as seen from the appropriate type of capital expenditure in the Curriculum of CFA Program ${ }^{17}$, are Expansion Projects as well as Replacement Projects to Maintain Business.

\section{Market Share Influence against Level of Profit}

The conclusions from the previous research, among others Chu et al. ${ }^{11}$, Laverty ${ }^{12}$, and Buzzell et al. ${ }^{13}$, can be confirmed empirically in research conducted in the entire regions in the company. Through this research it can be noted that market share has an impact on level of profit per region. In this case, it can be emphasized that market share is key to the level of profit or profitability.

The large size of the company's customer base offers several advantages. Buzzell et al. ${ }^{13}$ suggested the three 
advantages of economies of scale, market power, and quality management.

A focus on market share is documented in the Working Plan and Budget document "market leader position: strong portfolio in market share and revenue share." Market share becomes the power that is stated at the beginning of the business assumption. With its large market share, the company has better economies of scale, for example in terms of procurement, operations, marketing, and other costs; the opportunity to earn higher profits than smaller competitors; while generally reflecting the factor of a quality management. The main goal expected by the company is also stated specifically as "maintaining industry market leader." From the business assumption and that main goal, it can be concluded that market share is viewed by the company as a power that is owned.

\section{Entity Size Influence against Level of Profit}

The conclusions from previous research regarding the influence of size vary considerably. Toyin et al. ${ }^{14}$ and Kaen et al. ${ }^{15}$, in their research, found a strong positive relationship between company size and level of profit. Toyin suggested that profitability can be improved through the efficient management of fixed assets, such as through increased assets in the ICT (Information, Communication, and Technology) sector. Differing slightly, Kaen conducted research on intangible assets in the form of employees, concluding that profitability tends to increase as the number of employees increases but will decrease as companies become larger. Niresh et al. ${ }^{18}$, in contrast, found no relation between the size of total assets and profitability. The main cause expressed by Niresh in relation to a modern company was a shift in management focus from one of maximum profit to maximum managerial capabilities.

The company recognizes that asset management is critical to maintaining quality and ultimately affecting financial performance. This focus on asset management is specified in the corporate objective of "leading customer experience for legacy and digital business." The company's asset management focuses not only on tangible assets (e.g., base transceiver station or BTS), but also on intangible assets that are not reflected directly in the statement of financial position (e.g., employees).

\section{CONCLUSIONS}

CAPEX has an influence on the level of profit. This conclusion is supported by several studies, including Jiang et al. ${ }^{9}$, Chung et al. ${ }^{16}$, Cho et al. ${ }^{8}$, and Mutiara et al. ${ }^{7}$. Capital expenditure in the form of CAPEX in the company is focused more on CAPEX Network in order to increase Network Element capacity in the form of Infrastructure and Equipment, through Software and Hardware and spectrum optimization. In this case, the company is faced with a decision to make capital expenditures in the form of CAPEX to meet the demand from both the customer needs aspect and the updating technology aspect. The investment period is the determining factor as to whether CAPEX can affect the level of earnings in the period of performance; though it is shown in the conclusion above that CAPEX in period t-1 was proven to not be capable of influencing the level of profit, while CAPEX in period t-3 has a positive effect on the profit rate.

Market share has an influence on level of profit per region in the company. This conclusion is supported by several previous studies, among others Chu et al. ${ }^{11}$, Laverty ${ }^{12}$, and Buzzell et al. ${ }^{13}$. Market share has an influence on level of profit. A company with a large market share has power in the form of economies of scale, market power, and quality management.

\section{ACKNOWLEDGMENTS}

This paper was successfully presented at the $6^{\text {th }}$ International Accounting Conference $\left(27^{\text {th }}-29^{\text {th }}\right.$ August, 2017) in Yogyakarta, which was held by Universitas Indonesia.

\section{REFERENCES}

[1] Presiden Republik Indonesia. Peraturan Presiden Republik Indonesia No. 45 Tahun 2016 tentang rencana kerja pemerintahan tahun 2017, (2016).

[2] Telkomsel. Annual Report PT. Telekomunikasi Selular Year 2016, http://www.telkomsel.com/about/investor-relations/25-AnnualReport.html, (2017).

[3] Indosat Ooredoo. Annual Report PT. Indosat Tbk Year 2016, https://indosatooredoo.com/en/investor-relation/informasikeuangan/laporan-tahunan, (2017).

[4] XL Axiata. Annual Report PT. XL Axiata Tbk Year 2016, https://www.xl.co.id/aboutus/en/investor/information/annual-report.html, (2017).

[5] M. C. Jensen. Agency costs of free cash flow, corporate finance and takeovers, American Economic Review, 76(2) (1976) $323-329$.

[6] S. Hasnawati. Dampak set peluang investasi terhadap nilai perusahaan publik di Bursa Efek Jakarta, Jurnal Akuntansi Indonesia (JAAI), 9(2) (2005) 117-126.

[7] N. A. Mutiara, and B. R. Kartawinata. Pengaruh capital expenditure terhadap tingkat laba dengan kinerja perusahaan sebagai variabel moderator pada perusahaan jasa telekomunikasi yang terdaftar di Bursa Efek Indonesia periode 2009-2013, Proceedings SNEB 2014, (2014) 1-10.

[8] C. H. Cho, M. Freedman, and D. M. Patten. Corporate disclosure of environmental capital expenditures: a test of alternative theories, 
Accounting, Auditing and Accountability Journal, 25(3) (2012) 486-507.

[9] C. H. Jiang, H. L. Chen, and Y. S. Huang. Capital expenditures and corporate earnings: evidence from Taiwan Stock Exchange. Managerial Finance, Volume 32(11) (2006) 853-861.

[10] G. C. Lee and M. Nakanishi. Market-share analysis: evaluating competitive marketing effectiveness, Kluwer Academic Publishers, United States of America, (1988).

[11] W. Chu, C. N. Chen, and C. H. Wang. The market share-profitability relationships in the securities industry, The Service Industries Journal, 28(6) (2008) 813-826.

[12] K. J. Laverty. Market share, profits and business strategy, management decision, 39(8) (2001) 607-618.

[13] R. D. Buzzell, B. T. Gale, and R. G. M. Sultan. Market share-a key to profitability, Harvard Business Review, January (1975).

[14] E. Toyin, Olatunji, and T. A Adegbite. Investment in fixed assets and firm profitability: empirical evidence from the Nigerian banking sector, Asian Journal of Social Sciences and Management Studies, 1(3) (2014) 78-82.

[15] F. R. Kaen, and H. D Baumann. Firm size, employees and profitability in U.S. manufacturing industries, SSRN, 13 January 2013, (2003).

[16] K. H. Chung, P. Wright, and C. Charoenwong. Investment opportunities and market reaction to capital expenditure decisions, Journal of Banking \& Finance, 22 (1998) 41-60.

[17] CFA Institute. CFA Program Curriculum Vol 3, Pearson Custom Publishing, (2009).

[18] A. Niresh and V. Thirunavukkarasu. Firm size and profitability: a study of listed manufacturing firms in Sri Lanka, International Journal of Business and Management, 9(4) 2014. 